ISSN: 2349-2031

(C) 2019, THEIJSSHI

Research Article

\title{
Rationality of Information; How Embedded in Classical and Behavioural Theories in Investment Decisions
}

\section{George Obeng}

\section{University of Education, Winneba College of Technology Education Kumasi Faculty of Business Education} , Department of Accounting Education

\section{Corresponding author: George Obeng}

\author{
University of Education, Winneba, College of Technology Education Kumasi, Faculty of Business \\ Education, Department of Accounting Education P. O Box 1277 Kumasi, Ghana \\ E-mail: georgeobeng29@yahoo.com
}

\begin{abstract}
Literature posits that investors are informed by the capital structure and other classical theories in making their portfolio choices, dependent on available information. The choice should be rational to conform to set models and rules in theories to achieve the best of reward from the investment. The issue of rationality has not been specifically addressed to help the assessment of information and the investment environment for decision making. The study reviews literature on the rationality of information in investment decisions corresponding to traditional and classical financial models. Attention is directed to the fact that investors react differently to available information and how interpreted. The reaction of investors to information being relevant or rational is adjunct to their expectation and self-interest. It is observed that rationality of information and its relevance should be the responsibility of management to ensure rational investment decision. With information asymmetry information is expensive and investors will trade of information for debt capital, which response establishes the capital structure. In emerging and underprivileged economies development of the bond market will help the less endowed to develop entrepreneurial capabilities.
\end{abstract}

Key words: Classical Theories, Credible Information, Investment decision, Rationality.

\section{Section 1: Introduction}

Business finance and the offer of financial assets to the public to invest in the business have seen varying theories as to the rationality of behaviour on information in making investment decisions. Every investor has an interest to be satisfied in the process (Slain, 2002; Eaton, Eaton, Allen, 2005; Rutterford and Davison, 2007).). The interest is about the reward and security of the investment assets and to avoid any form of losses. Finance and investment as field of study directs its efforts on the protection of this interest. In this direction theories are postulated and pronounced in acquiring and managing the investment environment rationally to achieve the desired objectives (Lizieri, 2009; inByrne, Jackson, Lee 2013). As put by Byrne, Jackson \& Lee (2013), In terms of investor rationality, mainstream economics assumes that all market actors maximize their utility, subject to exogenously determined constraints, and to maximize is to be rational. Literature have theories as capital structure, pecking order, trade off, efficient market hypothesis, the efficient frontier line, capital asset pricing model and others. These theories and models fashion the rationality of behaviour (Kumar and Goyal, 2016; Byrne, Jackson, Lee, 2013) in their attempt to conceptualize the process of investment decision and portfolio choices. They assume the portability of the variables and assumptions to other geographic environments, cultures and

industries and are acceptable by all manner of investors despite their dispositions (Lizieri, 2009, p. 150; Byrne, et'al, 2013). The classical models (Markowitz, 1952; Sharpe, 1964; Fama, 1971; Merton, 1972), construct the efficient frontier, as observed by (Roll, 1977; in Livanas., 2008) is the single testable hypothesis associated with the Capital Asset Pricing Model (CAPM). There are other investment decision functions of several factors as market characteristics, individual risk factors and accounting information that may also influence investment decision (Jangogo \& Mutswenje., 2014). The theories may work to achieve desired objectives in a framework of rules and principles logically modelled with flow of information credible for a course that can be achieved in some circumstances and not others. The rationality of information for rational investment behaviour and decision is addressed in a process that can be seen in two phases as; data collection processes and cognitive processes. For the investment decision to be rational the data collection process and cognitive behaviour should be carried out rationally. It is important to acknowledge and appreciate the need of relevant information in the decision process. Investors have different backgrounds with objectives driven by factors difficult to synchronize and portable in every environment or industry and cultures. They rely mostly on information in the market to 
make their decisions which information should be credible. Neoclassical economic models suggest that the stock market would function efficiently when market participants are rational and fully process all the available information in making investment decisions in an unbiased way (Fama, 1970; Kumar and Goyal, 2016; Mohammed Tariqul Islam Khan, Siow-Hooi Tan, Lee-Lee Chong, 2017). Despite the required credibility of information investors' behaviour and reaction may be a matter of their psychological and emotional impulse that may finally direct them in their choice making as postulated by behavioural finance. Behavioural finance challenges the rationality of decision made under the classical models. It is possible to get such emotional behaviours modelled to meet set patterns and principles repeated over time in some environments as a practice and cultures difficult to be defiled. The emotional behaviours and responds to the market characteristics may not conform to the rationality of the classical models but metamorphose to take shape as prescribed by the mental impulse of the investor. There may be different investors with different objectives, interest and utility, information needs and disposition. There could be institutional investors (Islam Khan et'al, 2017) professionals, experts, insiders and the ordinary investor. Institutional investors are considered as rational and trade most of the stocks better informed, with an increasing tendency that they would use all the available information in their decision making thereby leading to an efficient market (Islam Khan et'al, 2017). Contrary to this view, the concept of bounded rationality suggests that individuals can only process a limited set of information available on the market (Islam Khan et'al, 2017). Limited human capacity hinders processing a broader set of information (Simon, 1957; Miller, 1957; Kahneman, 1973 in Islam Khan et'al, 2017)). Therefore, instead of using all the available information, individuals typically reduce the amount of information used to a more manageable set (Shiller, 1989; Scharfstein and Stein, 1990; Coval and Moskowitz, 1999). Along the lines of this argument, institutional investors also confine their information sources to selective information. Kong and Kong (2015) find that institutional investors behave speculatively resulting in market inefficiency. This result and development has brought about behavioural finance seen to be an alternate to the traditional financial theories. This cannot be so because the two should work together in a common process to arrive at an investment decision. It is important then to understand how investors direct their investment decision not necessarily underpinned by the rationality of the classical models but rather complement the analyzes through the cognitive functions and impinges that works on the rational information presented to make the final decision. This may radically deviate from or confirm the conclusion of the rational theories dependent on the available information and how processed, analyzed, interpreted and used to derive the final decision. The paper directs attention to investment behaviour of investors, consequential to reaction to available information, which impinges and impels psychological emotions either as extension or deviation and challenge to rational response epitomized by classical financial models. The rationality syndrome also suggests investors to be risk averse and may avoid a firm with geared capital structure to escape the risk of financial distress. Subjecting environments like emerging and less endowed economies with information opaqueness and uncertainties to this philosophy is diminish the desire of developing entrepreneurial initiative in such societies. Investment with debt capital thrives in such environment exposed to information asymmetry (Obeng, up); as such developing the bond market may provide an intervention for entrepreneurial development. The work addresses how to source information, the distinction between rationality and irrationality of information, factors determining and affecting information rationality and how management irresponsibility of ensuring credible information leads to material misstatement. Assessing the misstatement and how it is affecting information rationality that may give rise to ambiguity and irrationality in investment decision is paramount. The remaining work is segmented on; section two focus on classical financial models impelling investment decisions, section three is on rationality and irrationality of financial information in portfolio investment decisions, section four considers management responsibility for ensuring credible information, material misstatement in information and ambiguity in decision making, finally section five on conclusion and recommendations.

\section{Section 2: Classical Financial Theories/Models Impelling Investment Decisions}

This section reviews literature on theories/models conceptualizing behaviour of investors regarding their interest in the firm and how to optimize and protect them. It analyzes the rationality of the theories/model and how they impel investment decisions. Traditional theory assumes that investors' decisions are based on the expected utility theory. The expected utility theory believes in the concept of rationality with investors making consistent and independent decisions among varying and available alternatives (Kumar and Goyal, 2016). Investors build their investment portfolio on the basis of available information in the financial market

\subsection{Share Price Behaviour}

Share price behaviour the theme under this section focus on how some classical theories influence investors' preference and choice. Share price behaviour and the influence on investment decision expresses different views on market behaviour and theories developed to explain the movement in share prices and guide investors' decision on share acquisition and disposal. The theories for consideration are;
a. fundamental analysis theory
b. technical analysis
c. random walk theory

\section{a). Fundamental Analysis Theory}

The fundamental analysis of share price valuation is the discounted present value of all future expected dividend payments on the share discounted at the shareholders cost of 
capital (Ross et'al, 2002).

The two basic formulae for price predictions are;

a. Constant payment of dividend every year for a foreseeable future given as

$$
\begin{array}{rlr}
\mathrm{MV}=\frac{\mathrm{d}}{\mathrm{r}} & \text { or } & \underline{\mathrm{d}} \\
& & 1+\mathrm{r}
\end{array}
$$

Where MV is the market price of the share excluding dividend $\mathrm{d}=$ is the annual dividend per share

$r=$ is the shareholder's cost of capital (require rate of return)

b. Dividend growth at constant rate (g) every year for a foreseeable future;

$$
M V=\frac{d(1+g)}{r-g}
$$

Where;

$\mathrm{d}=$ is the dividend in the current year (year o)

$\mathrm{d}(1+\mathrm{g})=$ is the expected future dividend

It is difficult to determine the return to be expected on current retain earnings as details on forthcoming projects are not generally public (Ross et'al, 2002). Therefore current dividend payment is used in the analyses. Dividend payable cannot be a true reflection of the business earning. Payment is at management discretion and the accounting and financial statement information flout with conventions and assumptions may not be relevant enough to reflect the true position of the firm's business

A change in interest rate or rates of return upwards occasion market prices of shares to fall and when there is decline in interest rates prices will rise.

With the rise in interest as against the existing rate on the share, investors will seek new opportunities therefore; the price of the share will fall for lack of attraction. Likewise if the interest rate of the market declines, as against that of the share, the price of the share will rise because more of the shares will be demanded by investors.

The formulae and their variables that guide the predictions of share values and prices based on which investors may decide to acquire or disposed of a share depends on available information that shapes the behaviour of the investor ( $\underline{\text { Spetzler, }}$ Winter \& Meyer, 2016). It is management which decides the accounting principles in preparing the financial statements and the accounting bases and policies to determine the valuation of assets and liabilities and account balances making up the financial information. Quality information must be both relevant and reliable. Information is relevant when it helps us anticipate the value outcomes and must be reliable, drawn from trustworthy sources in a way that captures the expert's judgments and minimizes the impact of decision traps and biases (Spetzler, Winter, \& Meyer, 2016). The fundamental analysis uses data or information from financial statements prepared by management full of assumptions and conventions which may not reflect realities on ground. Estimates made from such sources may also be distorted by such assumptions. To ensure the relevance of such information effort should be made to adjust such assumptions in accordance with the needs, disposition and background of investors.

\section{b) Charting or Technical Analysis}

Charting is a technical skill in presenting past data on visual mode of presenting past price behaviour and patterns of share prices to help predict future price direction. The expectation is that prices will follow similar pattern and repeat itself over time. There is no certainty that every major price movement can be predicted with accuracy the correct investment decision, because of lack of relevant information. Charting is concerned with share prices and is the most up to date information about the company. Chartists are not concerned with predicting price change but primarily interested in trend reversals, which is further proof to provide information for investment decision. For the information provided by the chartist to be rational there should be accepted standards, principles and rules acceptable and logical to provide a credible base to make a good decision. It is the responsibility of management to ensure that the models for charting are generated on the bases of sound principles in developing financial information.

\section{c) Random Walk Theory}

Random work theory is consistent with the fundamental theory of share values. It envisages an intrinsic share prices dependent and reflective on;

a. The fortunes of the company that is if the company is doing well it will reflect in the values or prices of the company.

b. The expectations of investors. If investors are with high hopes and view that there are good prospects ahead it will compel them to demand more of the share and push the prices up.

The theory assumes that, all relevant information about the company is available to all potential investors who will act upon the information in a rational manner.

The intrinsic value of the share price changes as new information becomes available and that investors will behave and react with direct response to price movement. Actual price will fluctuate at random from day to day around the intrinsic value.

It is important to note that random movement in share prices will occur if the stock market operates efficiently and makes information about companies' earnings, dividends and other vital indicators of the company freely available to all participants in the market.

\subsection{The Efficient Market Hypothesis}

The Efficient Market Hypothesis (EMH) theory developed by Fama (1965) posits that Market (Stock Exchanges) is efficient where;

a. The prices of securities bought and sold (traded in) reflect all the relevant and available information known to the buyers and sellers. This means share prices change quickly as and when new information is made available about future prospects and the share reflects the market position.

b. No individual dominates the market

c. Transaction costs of buying and selling are not so high so as to significantly discourage trading. 


\section{George Obeng / Rationality of Information; How Embedded in Classical and Behavioural Theories in Investment Decisions}

The theory states that the financial markets do not allow investors to earn above-average returns without accepting above average risk (Anspach, 2017; Bank \& Brustbauer, 2014 in Zahera \& Bansal, 2018). Efficient market hypothesis explains that stock markets are efficient and the share price incorporates all the available information. In fact, the classical finance theory is built on the efficient market hypothesis (Zahera \& Bansal, 2018).

\section{Weak Form Efficiency}

Weak form of efficiency demonstrates the changes in share prices as a response to past information which is known to investors. That is, nobody can detect mis-priced securities and "beat" the market by analyzing past prices (Clarke, Jandik, \& Mandelker (ud); Rothbort, 2009). Share prices do not change in anticipation of new information being announced. Information arises unexpectedly and changes in price should occur in a random fashion. The market is weak if it fully incorporates the information in past stock prices.

Stock market displays weak-form efficiency based on the principle that;

a. share prices changes at random

b. there is no connection between past price movements and new share prices changes.

\section{Semi strong form of Efficiency}

The understanding here is that current share prices reflect;

a. all available information about past price movements and their implications

b. all knowledge which is available publicly which is relevant to the valuation of the shares

The efficiency is the ability of the market to anticipate share price changes before new information is publicly announced and made known (Clarke, Jandik, \& Mandelker (ud); Rothbort, 2009; Anspach, 2017)

\section{Strong form Efficiency}

Strong form efficiency proves that share prices reflect all information available from;

a) past price changes

b) public knowledge anticipation

c) insider knowledge available to specialists or experts (investment managers)

The information set of past prices is a subset of the information set of publicly available information which is also a subset of all information including insider information. If today's prices reflect all information both public and private (insider) the market is strong form efficient. The fundamental analysis and efficient market hypotheses have been challenged as to its correctness (Causi, 2017; (Clarke, Jandik, \& Mandelker (ud); Rothbort, 2009; Bank, Brustbauer 2014); Anspach, 2017). Anomalies about Efficient Market Hypothesis revealed by Clarke et'al (ud) are the issues of; over-reaction and underreaction affecting price changes in the market as posited by DeBondt \& Thaler and Ball and Brown (1968); value versus growth where participants in the market over estimate future growth rates for glamour stocks (high book value) relative to value stocks (low book value); and small firm effect where average returns are too high to be justified by CAPM posited by Rolf Banz (1981).

The important factor about the efficient market hypothesis is its development based on the work (s) of information emanating directly from the firm and its activities to the market with limited assumptions from analysts and experts. Investors being rational should react and behave differently and randomly, towards information made available by the firm, depending on their interest, uses and understanding of the information. The information from the market is generally rationalized on set rules but it is the individual investor who decides the choice and direction of the investment. Christiansen \& Varnes (2008) find from their study that the set of rules for conducting portfolio meetings was only partially followed and anticipated a framework for understanding how portfolio decision making is shaped and melded. The framework is developed through appropriate decision making rather than by following the normative calculative approach. Clearly investors are influenced by available information to react and behave accordingly in making their preference ordering and investment decision that finally gives the firm its capital structure. The determining factor is how relevant is the information underlying the various theories and models to make an informed analyses, draw relevant conclusions to guide investors to make an informed investment decision.

These models are hypothetically developed to test and predict future return outcomes and as a guide to investors. These are the works of experts and financial analyst depending on the information from the financial market as provided by the agents of the firm and regulatory bodies or generated by experts in their own experience from the market. The information should be credible with no ambiguity and inconsistencies. The more relevant, timely and the understandability of the information the greater the probability that investors' behaviour will be influenced to make investment decision rationally. They as well take advantage of the prevailing opportunity than to rely on just the capital structure and hypothetical theories. Investors will need better judgement to make a final decision. The managers of the firm own a responsibility of care, utmost good faith and due diligence to provide users of the information credible by all standards devoid of any ambiguity and inconsistencies. Even though managers may not know all manner of persons who may rely on the information provided, they own it as a duty to prepare financial information for the market in accordance with established standards and regulations

\section{Section 3: Sources and Credibility of Information for Investment Decisions}

This section looks at the issue of the investor being rational in making investment decision. It covers the information needed by the investor to make his decision and how they are informed by that information. The source, credibility of the information, it's rationality to meet the satisfaction and interest of different 


\section{George Obeng / Rationality of Information; How Embedded in Classical and Behavioural Theories in Investment Decisions}

investors and their disposition is considered.

Investors normally rely on available information to make decisions in their portfolio preference ordering. Information acquisition affects trading (Abreu and Mendes, 2012), risk taking (Anagol and Gamble, 2013), portfolio diversification (Abreu and Mendes, 2010), and portfolio performance (Islam

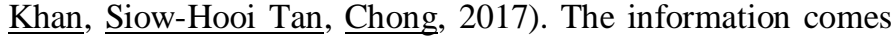
from different sources and types, however it should be of importance, adequate, relevant, reliable and credible for the investment decision (Arnswald, 2001; Menkhoff et al., 2006; Menkhoff and Schmidt, 2005; Menkhoff and Nikiforow, 2009). The information may come from the management of the firm, the industry or market publications, professionals and financial experts, public regulatory institutions, and other unstructured and informal sources. The information may be fundamental (Menkhoff, 1998; Arnswald, 2001) and non fundamental as technical analysis (Grinblatt et al., 1995; Barberis and Thaler, 2003) to the decision process. Fundamental information include company's stock characteristics, financial situation, industry and sectoral information and non fundamental comprising technical analysis like chart analysis, and moving averages (Islam Khan, Siow-Hooi Tan, Chong, 2017). Information from management comes in the form of annual financial statements (Shaheen, 2010; Abdulkadir, Abubakar \& Danrim, 2016; Puspitaningtyas,) comprising; performance statement for the period under review, the state of affairs as at the final day of the year or period of operations, the cash flow statements and the notes explaining how certain figures are arrived at. Industries establish bodies that look into the operations of individual firms of the industry to provide them with the necessary guidelines and tools to achieve their objectives in efficient manner. The bodies conduct research to update the current happenings, challenges, legislation, innovations and opportunities in the industry. They may publish their findings, views and other information relevant to the member firms in the conduct of their activities in bulletins and journals. They may also provide advice on financial and economic trend, labour, equipment and materials, legal, socio-cultural and environmental challenges. There are also professionals in any given industry who operate privately as experts and conduct research and analysis for the benefit of their clients and other interested parties including investors. Governments for the interest of the public enact legislation to guide the operations of the economic activities of firms in the country. The varying legislations under regulatory bodies are to protect the interest of the state in general, individual members of society, workers security, environmental issues and any other matters of public concern. The unstructured and informal source of information may include; direct interpersonal communications, such as unsystematic, word-of-mouth communications (Shiller and Pound 1989; Ivkovic and Weisbenner, 2007 in Islam Khan, Siow-Hooi Tan, Chong, 2017). There is enormous volume of information from which selection is made for the investment decision. Without information there is nothing like rationality of information or investment decision. As claim by Bell (2011) the rationality assumption is limited by time, information availability and cognitive ability. Bell (2011) further stressed that rationality assumption also ignores important variables for the decision-making process such as emotions, morals and ethics, image, ego, social status, context and pressure. These variables, are not limitations, they form part of the cognitive and psychological processes in investment decisions. They work on information according to the investors understanding and interpretation of data. From the cognitive processes is the relevant information selected for the investment decision that should be rational resulting from rational phenomenon. The rationality or irrationality of the decision is dependent on the information from management and how communicated and other behavioural factors evolved from society.

The source and type of information in investment decision may be identified and used by different investors in different ways. Individual investors perceive stock market returns as important fundamental information (Warther, 1995, in Islam Khan, SiowHooi Tan, Chong, 2017). In Germany fund managers view economic and political facts as the primary fundamental information source for their decisions (Menkhoff, 1998 in Islam Khan, Siow-Hooi Tan, Chong, 2017) and seek information from colleagues and other market participants to confirm their own decisions besides using fundamental information (Arnswald (2001).

Investors seek information from informal communication including direct interpersonal communications, such as unsystematic, word-of-mouth communications Shiller and Pound 1989; Ivkovic and Weisbenner (2007 in Islam Khan, Siow-Hooi Tan, Chong, 2017). Investors using word-of-mouth communication for their decision do so to reduce search costs and lack of expertise (Islam Khan, Siow-Hooi Tan, Chong, 2017). Investors give higher emphasis to specific information channel in their investing decisions (Islam Khan et al, 2017) and that information acquisition largely results in higher trading with frequent adjustment in investors' portfolios (Peress, 2004) and for the group of overconfident investors (Guiso and Jappelli (2006). Information from trustworthy sources contributes more toward active trading than information acquired from less reliable sources (Epstein and Schneider, 2008).

Information sources used by investors strengthen the relation between frequencies of information acquisition and trading intensity and that when overconfident investors collect information via friends and family, they trade less (Abreu and Mendes, 2012).

Non-overconfident investors increase their trading frequency when using specialized source of information (Islam, 2017). Extraversion and conscientiousness positively moderate the association between information acquisition and trading frequency, whereas openness negatively moderates the association between information acquisition and trading frequency Tauni et al. (2015). To invest in risky assets the quality of information on risk return relationship is paramount (Grossman and Stiglitz (1980). They contend that the quality of information affects investors demand for risky assets and they 


\section{George Obeng / Rationality of Information; How Embedded in Classical and Behavioural Theories in Investment Decisions}

pay more attention to quality and precise information, which induces them to invest in risky assets. On the other hand volume of information has no impact on portfolio risk taking (Beshears et al, 2011). Literature suggests that information sources drive the portfolio composition of investors (Kumar and Goyal, 2016). Abreu and Mendes (2010) in their work on the Portuguese Securities Commission find that information from specialized newspapers and the stock exchange bulletins of quotations increases individual investors' portfolio diversification. Patel (2012) finds that investors can gather and analyze a large amount. He observed that other forms and types of information of importance to investors are assetspecific information, current economic conditions, and expectations about future economic conditions. Patel (2012) finds forward-looking economic information to be the most relevant to the investing decisions of investors when other types of information are vague and ambiguous. These varying sources of information and their relevance in investment decision making is largely the hand maid of management. Financial information from management is captured by all interested persons and stakeholders for their analyses and consumption. The users of such information from management available in the financial market and authenticated by statutory and regulatory institutions and bodies have every right and privilege to assume its credibility and that the information has been rationally produced and presented. However, the unavailability of the right information or information manipulated to attract unsuspected investors intentionally cannot help investors achieve their investment goal rationally.

\section{Section 4: Rationality of Information}

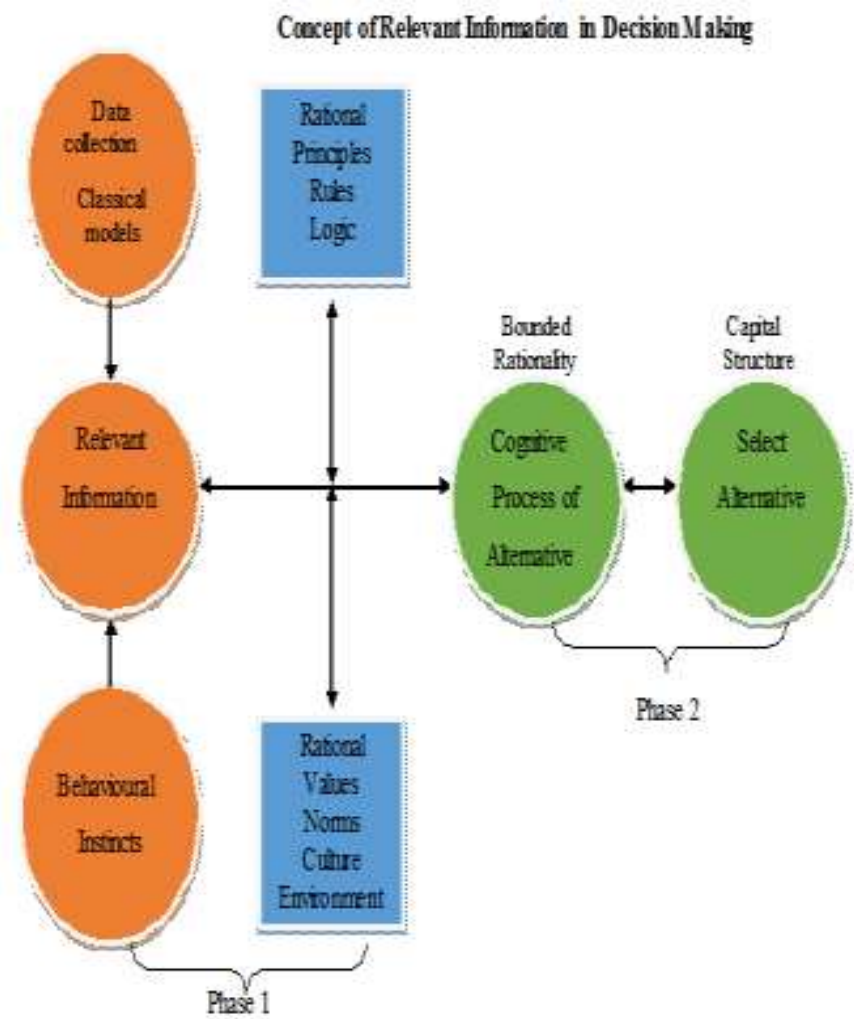

Investors are expected to conduct themselves rationally to make the best out of the information available for their investment decision (Nozick, 1993) and the information itself should be rational. Rational means logical, reasonable, intelligent and prudent (www.memo-book.net). Rational is seen as following some rules, principles and standard as a guide to achieve an objective within a given framework. Investment decision is a process that can be broken down into two phases as data collection processes and cognitive behaviour processes. For the investment decision to be rational the data collection processes and cognitive behaviour processes should be carried out rationally. Rationality as a principle should be recognized and observed in making any selection and inputs for investment decision process. The first process of data collection phase takes two steps; hard processing that identifies and recognizes the global sources and type of information to form a population for the decision and the second step cognitive and soft processing to select the relevant information from the global or population that suits or meets the needs and interest of the decision maker or investor. The information selected here is acknowledged to have been rationally prepared to meet all standards in logical and regulatory terms and other disclosure requirements. The cognitive and the psychological phase of the investment decision process is the analytical phenomenon of digesting, assimilation and the interpretation of the hard data derived at the first phase. The second phase of the investment decision process also takes two steps. The first step develops alternative cognitive models with different outcomes. The second step is the cognitive behaviour to select the best alternative influenced by the understanding, interpretation of possible outcomes and the disposition of the investor. It can be seen that the investment processes have two major phases summarize as the information phase and decision phase. The cognitive and the psychological phenomenon facilitate the selection of the best alternate among the lot and possible outcomes in the processes. This being the case then it should be realized that the cognitive behaviour that select the best source of information in the first phase is what is referred to as bounded rationality ( $\underline{\text { Simon }}$ (1956, 1982). The bounded rationality becomes the bases for the cognitive and the psychological phenomenon that facilitates the selection of the best alternate. In the absence of rational data or information and rational cognitive processes the resulting decision will be considered irrational. For that matter the brain is considered to be carrying its processing activities abnormally in psychological terms, which is not acceptable. The brain works on the information given and the mindset of the investor; therefore if the information is good the outcome is good. The mindset depends on where the investor is coming from, his environment and deposition. Kumar and Goyal, (2016) observed that rational decision-making is combined with a structured or logical thought process to achieve an efficient and optimal result. There is the theory of rational choice (Kumar and Goyal, 2016) that impel decision makers to consider a set of alternatives from different scenarios before selecting a choice. To attain full rationality, people necessitate unlimited cognitive capabilities (Kumar and Goyal, 2016). To ensure rationality of decision making, two basic models have been proposed: rational model and bounded 


\section{George Obeng / Rationality of Information; How Embedded in Classical and Behavioural Theories in Investment Decisions}

rationality model. Rationality in decision-making according to (Mintzberg et al. 1976 in Kumar and Goyal, 2016) has a threestage model of strategic decision process, namely; identification of problem, development of alternative solutions to the problem and finally, the selection of the alternative for an optimal solution. In the absence of adequate and credible information and efficient assimilation of information in cognitive terms (Kumar and Goyal, 2016), rational decision making is a nightmare giving way to the concept of bounded rationality (Simon (1956, 1982). The concept of bounded rationality suggests that individuals can only process a limited set of information available in the market (Islam Khan, SiowHooi Tan, Chong, 2017). For want of human capacity in processing a broader set of information (Simon, 1957; Miller, 1957; Kahneman, 1973), individuals typically reduce the amount of information available and needed to a more manageable set (Shiller, 1989; Scharfstein and Stein, 1990; Coval and Moskowitz, 1999). Musshoff \& Hirschauer (2011) in their work on behavioural economic analysis of bounded rationality in farm financing decisions find that farmers in Germany exhibited limited availability of information and limited cognitive abilities to process the available information, indicating bounded rationality at work. The problem here is that the concept of rationality and bounded rationality alternate, that is they are mutually exclusive. However, this work is putting up an argument that the two concepts cannot be separated but are bed fellows in a complete phenomenon in decision making. Investors are exposed to overwhelming source of data and information from which they select their needs in accordance with their interest and disposition as directed by their cognitive and psychological capacity shaped by their environment. Kahneman and Tversky, (1979) developed the prospect theory for decision-making under uncertainty, a critique to the expected utility theory. Prospect theory believes that some psychological factors influence the investors' decision-making deviating them from the rationality (Kumar \& Goyal, 2016). Furthermore from the observation of Kumar \& Goyal, (2016) investors' rational decision-making process includes the procedures of identification of demand as quoted above, it can be deduced that their position supports the fact that the investment decision process combines data collection and information gathering at one side and the cognitive processes and phenomenon to select the best alternate information in the decision making process and they are not separate events. Rationality of the information selection is complemented by the cognitive and psychological factors in investment decision making. It is suggested that investors rarely follow logical procedure in investment decisions due to limited information. Research on individual investors conducted in investment decision in various countries has shown the display of behavioural biases (Kumar \& Goyal, 2016). The concepts of rationality and irrationality are not clearly distinguished and determined appropriately which saw Simon (1956, 1982) suggesting and substituting the term with the concept of bounded rationality. Researchers suggest that bounded rationality is not the irrationality and, agents are also not irrational; they are bounded rational (Kumar and Goyal, 2016). This shows and supports the fact that data collection into the global population of information is worked on cognitively to sieve information to select what information is needed for the second phase of the investment decision process. The other factor not considered as why investors select limited information is the cost of obtaining information (Obeng, up). If the cost of information gets higher, investors will, as rational being, conduct cost benefit analysis and if cost is higher than the returns and other related benefits they will trade off part of the information for savings in returns and increase their interest in the investment (Obeng, up). Therefore selecting limited information for investment decision should not be alluded to limited cognitive capacity. It is important to consider other works in other areas that fault the cognitive and the psychological processes in investment decision making. It should be understood that the rationality of investment decision is dependent on available credible information to the investor and how rationally developed. Information comes from management and investors identify, select, digest and interpret information as presented and how they understand it. The rationality or irrationality of information and resultant decision, how limited and faulty should be at the door steps of management. Information not developed rationally to follow a concerted logical flow of thought will lead to ambiguous decision that may be tantamount to decision irrationality an abnormality which is not the fault of the investor.

Chaudhary (2013) looked at approaches to the investors to invest in the stocks and bonds, and explained the importance and application of behavioural finance in investment decisions. Chavali and Mohanraj (2016) found the relationship between demographic characteristics of investors and find that gender is the most important variable impacting the investment decisions of individual investors. The stronger managerial incentives are a result of proper governance and it reduces the herding effect to minimize the poor performance (Casavecchia, 2016). Chhabra and De (2012) find that there is a significant impact of the result of the recent past failures on the current potential to invest. Papadovasilaki et al. (2015) find that there is relationship between early investment experiences (gain or losses) and subsequent portfolio investment decisions are positive and both factors are strongly correlated. Maung and Chowdhury (2014) suggest the right timing, hot and cold, of equity issuances and other investments in real fixed assets for the corporate investors. The hot issue market, where the information asymmetry is considerably low, information exchange is high between corporate managers and outside investors. The cold issue market is where the information is highly asymmetrical. In high issue market, the firms have greater opportunities to select the best investment, issuances are less costly, and firms can raise an adequate amount of fund from the market. The Maung and Chowdhury (2014) observation is alluding to the fact that management makes the difference in providing credible information and communicating same, the investor taking cognizance of his/her environment and disposition to arrive at rational investment 


\section{George Obeng / Rationality of Information; How Embedded in Classical and Behavioural Theories in Investment Decisions}

decision. Information comes from different sources in some form, nature and classifications. Users have the right to believe and accept the information to be true and credible in any event and circumstances in making their decisions. Any information on the firm available in the market emanate from management and agents of the firm. Management, in presenting the financial statements are making some assertions of facts (Osuala, Ugwumbaand, Osuji, Okpara, 2012; Shaheen, 2010). They are disclosing essential information in accordance with accepted standards to meet the needs of users (Osuala, Ugwumbaand, Osuji, Okpara, 2012; Shaheen, 2010; Zuca, 2009). In the financial statements management is claiming that the individual items are correctly described, show figures which are arithmetically correct or fairly estimated, and the accounts as a whole show a true and fair view (ISA 500). The issue of rationalism is then complete on the part of the investor in his decision with no doubt and any limitation. The rationality or irrationality of the decision made by investors is dependent on the management and their financial information presented which should be devoid of any material misstatement and inconsistencies that can affect the judgment of investors. In the absence of credible information from management, investors' decision will be fraught with biases and distortions. Investors then will prefer secured securities like bonds to assure them of their returns and value of their investment assets.

\section{Conclusion and Recommendations}

The paper considered the issue of rationality of information and classical financial theories in investment decision making. The issue of rationality has not been specifically addressed in literature to help the better assessment of information and the investment environment for decision making. Literature on the rationality of information and investment decisions corresponding to traditional and classical financial models and bounded rationality borrowed from behavioural finance cannot operate as separate theories in separate markets by any different sets of investors. Any effect on any investor in any market accordingly, may be due to the interpretation of information and its characteristics or features. Secondly the cost of information influences the volume of information to be selected for investment decision (Obeng, up), and not the cognitive capacity, which cost influence the investor to trade of information for debt capital. Classical theories or models are market oriented and their source of information is the financial information provided by management and other statutory and regulatory institutions and bodies as the first phase of the investment decision making process. The varying sources of information and their relevance in investment decision making is largely the hand maid of management. Financial information from management is captured by all interested persons and stakeholders for their analyses and consumption. The users of such information, from management available in the financial market and authenticated by statutory and regulatory institutions and bodies, can assume its credibility and rationality as presented. The selection of any limited information for any investment decision should be considered credible and the processes involved are done rationally. The findings from the work of Islam Khan, Tan, Chong, (2017) supported the limited information processing of bounded rationality. Even though information used may be from fundamental and technical indicators or non fundamental sources the investors' selection of limited information for their investment decision does not establish irrational information or decision. Cognitive and psychological behaviour in investment decision are specific and individual oriented acting in furtherance of the classical rational models, assimilating the market information into action, in the second phase of the decision process. Cognitive and psychological behaviour cannot assume to work same among all individuals and group of investors and be portable to all geographical, cultural environments and circumstances. It cannot assume investors to be a body with similar interest and identity. There are different investors; individuals, institutions, and professionals all with different backgrounds, interest and objectives. Likewise the source and type of information and its credibility and understanding may be seen differently by different investors and different group of persons. The cost of information, however limited, informed the investor to achieve his goal, and trade expensive information for debt capital. The response of investors to information establishes the capital structure as against management wishes. In the absence of relevant information, particularly in emerging and less developed economies consideration should be given to the development of the bond market to help entrepreneurial development.

\section{Recommendations}

Financial information coming from management as presented in the financial statements should be devoid of any material misstatement of fraudulent manipulation and falsifications. The financial statements and presentation should be in accordance with generally accepted accounting standards and other statutory and regulatory requirements. This will assure the financial systems and market of the credibility and rationality of the information presented which investors can rely for their investment decisions.

Substantial improvement should be made in the type, form and mode of communication of information of financial products given to investors (Nenkov et al. (2009), This can result in making consumers aware of the pros and cons of investment decisions and subsequent alleviation of biases in the investment decision-making.

The responsibility of ensuring credibility and rationality should be at door steps of management. Management should be answerable to any lapses in the performance, stability and security of the corporate firm. To put the blame on the investors and other stakeholders is an attempt to exonerate management from any wrong doing and escape liability for their actions and inactions.

To ensure duty of care and due diligence in performing their duties, management perks and allowances, apart from normal salaries, should be an appropriation of profits and not as an expense in the performance statement. 


\section{George Obeng / Rationality of Information; How Embedded in Classical and Behavioural Theories in Investment Decisions}

The internal audit function in corporate institutions and the external audit should be properly strengthened with staff of good integrity and independent of management to ensure that internal control systems put in place by management and statutory and regulatory provisions are adhered to.

In environments of information asymmetry attention should be given to the bond market development to help the underprivileged in society to develop their businesses.

\section{Acknowledgement}

I may want to express my gratitude to Dr. Dadson Awunyo

Vitor, of Kwame Nkrumah University of Science and

Technology for his immense support and contributions in various ways in my research work;

\section{References}

1. Abdulkadir, M., Abubakar, H., \& Danrim, L. M. (2016): The effect of financial reporting on investment decision making by banks in Nigeria, International Journal of Research in Finance and Marketing, Vol. 6 issue 4

2. Abreu, D. and Brunnermeier, M.K. (2003), "Bubbles and crashes", Econometrica, Vol. 71 No. 1, pp. 173-204. [Crossref], [ISI], [Google Scholar] [nfotrieve]

3. Abreu, M. and Mendes, V. (2012), "Information, overconfidence and trading: do the sources of information matter?" Journal of Economic Psychology, Vol. 33 No. 4, pp. 868-881. [Crossref], [Google Scholar] [nfotrieve]

4. Anagol, S. and Gamble, K.J. (2013), "Does presenting investment results asset by asset lower risk taking?", Journal of Behavioural Finance, Vol. 14 No. 4, pp. 276300. [Crossref], [Google Scholar] [Infotrieve]

5. Arnswald, T. (2001), "Investment behaviour of German equity fund managers: an exploratory analysis of survey data", Deutsche Bundesbank Discussion Paper No. 08/01, Frankfurt. [Google Scholar]

6. Anspach, D. (2017), The Efficient Market Hypothesis in Simple Terms (Retrieved 22/03/18)

7. Baberis, N \& Thaler, R, (2003): A survey of behavioural finance handbook of the Economics of Finance Elsevier Science B.V

8. Bank, M., Brustbauer, J. (2014). Investor Sentiment in Financial Markets Working paper, University of Innsbruck

9. Beshears, J., Choi, J., Laibson, D. and Madrian, B. (2011), "Behavioural economics perspectives on public sector pension plans", Journal of Pension Economics and Finance, Vol. 10 No. 2, pp. 315-336. [Crossref], [Google Scholar] [nfotrieve]

10. Bell, H.A. (2011), Toward a value inclusive theory of economic decision-making: a 'new science' model", European Journal of Social Sciences, Vol. 21 No. 4, pp. 638-649. [Google Scholar] [nfotrieve]

11. Bodie, Z, Kane, A. \& Marcus, A. (2002): Investment $\left(5^{\text {th }}\right.$ ed.), Boston, McGraw-Hill Irwin

12. Brahmana, R., Hooy, C.W. and Ahmad, Z. (2014), "The role of weather on investors' Monday irrationality: insights from Malaysia", Contemporary Economics, Vol. 8
No. 2, pp. 175-190, available at: https://doi.org/10.5709/ce.1897-9254.139

[Crossref], [Google Scholar] [Infotrieve]

13. Causi, G. L. (2017); Theories of investor behaviour: From the Efficient Market Hypothesis to Behavioural Finance, Tallinn University of Technology

14. Chhabra, R. and De, S. (2012), "Are out-of-pocket costs over weighted relative to opportunity costs? A disposition effect based investigation", SSRN Electronic Journal, available at: https://ssrn.com/abstract=2022986 [Google Scholar]

15. Clarke, J., Jandik, T., Gershon Mandelker, G. (ud), The Efficient Markets Hypothesis (Retrieved 22/03/18)

16. Coval, J.D. and Moskowitz, T.J. (1999), "Home bias at home: local equity preference in domestic portfolios", Journal of Finance, Vol. 54 No. 6, pp. 2045-2073. [Crossref], [Google Scholar] [nfotrieve]

17. De Bondt, W. F. M. \& Thaler, W. (1985). Does the stock market overreact, The Journal of Finance, Vol. XI, No 3

18. Eaton C.B., Eaton F.D., \& Allen, W.D. (2005). Micro Economics Theory with Applications.

19. Toronto, Canada: Pearson Prentice Hall.

20. Epstein, L.G. and Schneider, M. (2008), "Ambiguity, information quality, and asset pricing", Journal of Finance, Vol. 63 No. 1, pp. 197-228. [Crossref], [Google Scholar] [Infotrieve]

21. Fama, E.F. (1970), "Efficient capital markets: a review of theory and empirical work", Journal of Finance, Vol. 25 No. 2, pp. 383-417. [Crossref], [Google Scholar] [Infotrieve]

22. Grinblatt, M., Titman, S. and Wermers, R. (1995), "Momentum investment strategies, portfolio performance, and herding: a study of mutual fund behaviour", American Economic Review, Vol. 85 No. 5, pp. 1088-1105. [Google Scholar] [nfotrieve】

23. Grossman, S. and Stiglitz, J. (1980), "On the impossibility of informationally efficient markets", American Economic Review, Vol. 70 No. 3, pp. 393-408. [Google Scholar] [nfotrieve]

24. Guiso, L. and Jappelli, T. (2006), "Information acquisition and portfolio performance", CSEF Working Papers No. 167, University of Naples, Napoli. [Google Scholar]

25. Islam Khan, M. T, Siow-Hooi Tan, Lee-Lee Chong, (2017) "Information sources and investing decisions - a path modelling approach", Managerial Finance, Vol. 43 Issue: 8, pp.928-947, https://doi.org/10.1108/MF-08-2016$\underline{0232}$

26. Ivkovic, Z. and Weisbenner, S. (2007), "Information diffusion effects in individual investors' common stock purchases: covet thy neighbours' investment choices", Review of Financial Studies, Vol. 20 No. 4, pp. 13271357. [Crossref], [Google Scholar] [nfotrieve]

27. Jagongo, A. and Mutswenje, V. S. (2014). A survey of the factors influencing investment decision: the case of individual investors at NSE; International Journal of Humanities and Social Sciences Vol. 4 No 4 (pp. 92-102). 


\section{George Obeng / Rationality of Information; How Embedded in Classical and Behavioural Theories in Investment Decisions}

28. Kahneman, D. (1973), Attention and Effort, Prentice-Hall, Englewood Cliffs, NJ. [Google Scholar]

29. Kahneman, D. \& Tversky, A. (1974): Judgment under uncertainty: Heuristics and biases in science Vol. 185, Issue 4157, pp $1124-1131$

30. Kahneman D., Tversky A. (1979), "Prospect Theory: an analysis of decision under risk",

31. Econometrica, Vol.47, no. 2, pp. 263-291.

32. Kong, G. and Kong, D. (2015), "Institutional investors' trading in speculation: evidence from China", South African Journal of Economics, Vol. 83 No. 4, pp. 617-631. [Crossref], [Google Scholar] [nfotrieve]

33. Livanas, J. (2008); Empirical Analysis of Investor Utilities in Investment Choice; Institute of Actuaries of Australia; Risk and Capital Management Research Conference 2008, Sydney, Australia

34. Lizieri, C. (2009), Towers of Capital: Office Markets and International Financial Services, Wiley-Blackwell, Chichester. [Google Scholar]

35. Markowitz, H. (1952), "Portfolio selection", The Journal of Finance, Vol. 7 No. 1, pp. 77-91. [Google Scholar] [nfotrieve]

36. Maung, M. and Chowdhury, H.R. (2014), "Is there a right time for corporate investment?", Studies in Economics and Finance, Vol. 31 No. 2, pp. 223-243, available at: https://doi.org/10.1108/SEF-08-2013-0112

[Link], [Google Scholar] \nfotrieve]

37. Menkhoff, L. (1998), "The noise trading approach questionnaire evidence from foreign exchange", Journal of International Money and Finance, Vol. 17 No. 3, pp. 547 564. [Crossref], [Google Scholar] [Infotrieve]

38. Menkhoff, L. and Nikiforow, M. (2009), "Professionals' endorsement of behavioural finance: does it impact their perception of markets and themselves?" Journal of Economic Behaviour \& Organization, Vol. 71 No. 2, pp. 318-329. [Crossref], [Google Scholar] [Infotrieve]

39. Menkhoff, L. and Schmidt, U. (2005), "The use of trading strategies by fund managers: some first survey evidence", Applied Economics, Vol. 37 No. 15, pp. 1719-1730. [Crossref], [Google Scholar] [nfotrieve]

40. Menkhoff, L., Schmidt, U. and Brozynski, T. (2006), "The impact of experience on risk taking, overconfidence, and herding of fund managers: complementary survey evidence", European Economic Review, Vol. 50 No. 7, pp. 1753-1766. [Crossref], [Google Scholar] [nfotrieve]

41. Miller, G.A. (1957), "The magical number seven, plus or minus two: some limits on our capacity for processing information", Psychological Review, Vol. 63 No. 2, pp. 81-97. [Crossref], [Google Scholar] [nfotrieve]

42. Obeng, G (up). Investment Decision; Information Driven and Preference Ordering

43. Osuela, A. E., Ugwumbaan, E. C., Osuji, J. J., Okpara, M. (2012). Financial statements content and investment decision - a study of selected firms, JORIND Vol. (2), www.transcampus.org/journals.

44. Papadovasilaki, D., Guerrero, F., Sundali, J. and Stone, G.
(2015), "How important are early investment experiences on subsequent investment decisions? A laboratory experiment on asset allocation”, Managerial Finance, Vol. 41 No. 6, pp. 582-590, available at: https://doi.org/10.1108/MF-09-2014-0246 [Link], [ISI], [Google Scholar] [nfotrieve]

45. Patel, S. (2012), "Economic optimism, information uncertainty and future investment decisions: evidence from the mutual fund industry", available at: http://dx.doi.org/10.2139/ssrn.1977974

(accessed November 3, 2015). [Google Scholar]

46. Peress, J. (2004), "Wealth, information acquisition, and portfolio choice", Review of Financial Studies, Vol. 17 No. 3, pp. 879-914. [Crossref], [Google Scholar] [Infotrieve]

47. Puspitaningtyas, Z. (ud.). How accounting information is useful for investors, www.academia.edu./237544. (350354)

48. Ross, S. A., Westerfield, R. W., \& Jaffe, J. (2002): Corporate finance $\left(6^{\text {th }}\right.$ ed.), Boston, McGraw-Hill Irwin

49. Shaheen, Y. (2010). The perceived usefulness of information for investment decisions: Evidence from Palestine Security Exchange, Hebron University Research Journal Vol. (5) No. (2) pp (283 - 307)

50. Shiller, R.J. and Pound, J. (1989), "Survey evidence on diffusion of interest and information among investors", Journal of Economic Behaviour \& Organization, Vol. 12 No. 1, pp. 47-66. [Crossref], [Google Scholar] [nfotrieve]

51. Scharfstein, D. and Stein, J. (1990), "Herd behaviour and investment", American Economic Review, Vol. 80 No. 3, pp. 465-479. [Google Scholar] [nfotrieve]

52. Sharpe, W.F. (1964), "Capital asset prices: a theory of market equilibrium under conditions of risk", Journal of Finance, Vol. 19 No. 3, pp. 425-442. [ISI], [Google $\underline{\text { Scholar] [nfotrieve] }}$

53. Simon, H. A. (1955), A behavioural model of rational choice, The Quarterly Journal of Economics, Vol. 69, Issue 1

54. Spitzier, C., Winter, H. \& Meyer, J. (2016). Relevant and reliable information, Wilky online library, https://doi.org/10,1002/978119176657,ch06

55. Whittington, O. R., \& Pany, K. (2004), Principles of auditing and other assurance services $\left(14^{\text {th }}\right.$ ed.), Boston, McGraw Hill Irwin

56. Satish Kumar, Nisha Goyal, (2016) "Evidence on rationality and behavioural biases in investment decision making", Qualitative Research in Financial Markets, Vol. 8 Issue: 4, pp.270-287, https://doi.org/10.1108/QRFM-05$\underline{2016-0016}$

57. Mohammad Tariqul Islam Khan, Siow-Hooi Tan, Lee-Lee Chong, (2017) "Information sources and investing decisions - a path modelling approach", Managerial Finance, Vol. 43 Issue: 8, pp.928-947, https://doi.org/10.1108/MF-08-2016-0232

58. Musshoff, O. \& Hirschauer, N. (2011) "A behavioural economic analysis of bounded rationality in farm 
financing decisions: First empirical evidence", Agricultural Finance Review, Vol. 71 Issue: 1, pp.62-83, https://doi.org/10.1108/00021461111128165

59. Peter Byrne, Cath Jackson, Stephen Lee, (2013): "Bias or rationality? The case of UK commercial real estate investment", Journal of European Real Estate Research, Vol. 6 Issue: 1 , pp.6-33, https://doi.org/10.1108/17539261311312960

60. C (2008) (Copenhagen Business School, Copenhagen, Denmark)

61. Slavin, I.S. (2002). Economics $\left(6^{\text {th }}\right.$ ed). New York: McGraw Hill Irwin.

62. Syed Aliya Zahera, Rohit Bansal, (2018) "Do investors exhibit behavioural biases in investment decision making? A systematic review", Qualitative Research in Financial Markets, Vol. 10 Issue: 2, pp.210-251, https://doi.org/10.1108/QRFM-04-2017-0028

63. (www.memo-book.net).

64. Zuca, M. (2009). Relevance and credibility of the information from the financial statements, The Annals of the "Stefan Cel Mare" University of Suceava Facide of The Faculty of Economics and Public Administration, Vol. 9. No. 2(10) 